\title{
Animal Genetics and African Archaeology: Why It Matters
}

\author{
Diane Gifford-Gonzalez
}

Published online: 9 March 2013

(C) Springer Science+Business Media New York 2013

\begin{abstract}
This article introduces the special issue of African Archaeological Review on the relevance of African livestock genetics to archaeology on the continent. It shows how modern and ancient animal genetic research in Eurasia has substantially revised archaeological scenarios for the origins and spread of food production there. It argues that, in contrast to colleagues in Europe and Asia, Africanist archaeologists have generally been slow to engage in truly collaborative research with archaeogeneticists, with some notable exceptions. It builds a case that animal introductions and domestication are as much social, cultural, and economic processes as they are ecological in nature. Through examples, it outlines some profound selective effects that animal keeping has had on humans themselves. Building on the concepts of taste and embodied practice in Stahl's (2002) discussion of artifacts and differently scaled encounters with non-local commerce, it develops suggestions for archaeologically studying genetically distinctive domestic animals as part of local and long-distance economic systems. Finally, it comments on the issue's review articles and offers suggestions for ways to encourage stronger collaboration between archaeologists and genetic researchers.
\end{abstract}

Résumé Cet article montrent les façons dont les recherches génétiques animales modernes et anciennes en Eurasie ont révisé substantiellement les scénarios archéologiques des origins et de la propagation sur le continent. Il affirme que, par contraste avec ces colleagues en Europe et en Asie, les archéologues africanists ont généralement été lents à s'engager dans la recherche collaborative avec les archéogénéticiens, avec quelques exceptions notables. Il fait le cas que les introductions et les domestications sont autant des processus sociaux, culturels, et économiques qu'ils sont écologiques par nature. À travers des exemples, il résume quelques effets profonds selectifs que le gardiennage d'animaux a eu sur les être humains eux-mêmes. En prennant appui sur les concepts du goût et de la pratique

D. Gifford-Gonzalez $(\bowtie)$

Department of Anthropology, University of California, Santa Cruz, Santa Cruz, CA 95064, USA

e-mail: dianegg@ucsc.edu 
incarnés dans la discussion de Stahl (2002) des objets et des rencontres des échelles différentes avec le commerce non local, il avance des propositions pour l'étude des animaux domestiques génétiquement distincts comme un partie des systèmes economiques de longue-distance. Enfin, il commente les articles du numéro et offre les suggéstions d'encourager la collaboration plus étroite entre les archéologues et les chercheurs génétiques.

Keywords Archaeology $\cdot$ Africa $\cdot$ Genetics $\cdot$ Domestication $\cdot$ Trade

\section{Introduction}

Even casual visitors to African farming villages, pastoralist camps, towns, and city neighborhoods can testify to the remarkable integration of domestic animals into peoples' everyday lives, as well as to the adaptability of such creatures to living with humans. How these varied and complex systems of human-animal interaction emerged over the last eight to nine millennia is as yet not well understood, especially in those zones away from the documentary hand of artists and scribes, which in truth is most of Africa. Much as obsidians bear distinctive trace elements from their originating volcanoes, plants and animals carry the fingerprint of their ancestors' regions of origin in their genes, and their DNA can often be used to trace geographic patterns in the histories of human migration and exchange.

The purpose of this special issue is to convey recent findings from animal genetics on the history of domestic animals on the continent to Africanist archaeologists, and hopefully to underline the relevance of integrating such knowledge into our research programs. The impetus for this special issue was a well-received session at the 2008 Frankfurt meetings of the Society of Africanist Archaeologists, where animal geneticists presented findings on African species and, in a panel discussion, responded to questions from the floor. The positive tenor of queries and discussions was such that I resolved to try to bring a similar presentation of findings to publication, with an emphasis on bringing forward the work of younger animal geneticists as well as established authorities. The six papers in this special issue of the African Archaeological Review are all written by experts in modern or ancient DNA analysis. This issue follows closely on another special issue of African Archaeological Review (volume 29: issue 2-3, September 2012) that stressed the value of integrating human genetic studies' findings with those of linguistics and archaeology in tracing African history. Together, they may signal the opening of a new, more interdisciplinarily collaborative phase in Africanist historical research.

For many Africanist archaeologists, the basic principles of linguistics may be relatively more familiar than those of modern genetics. Though a zooarchaeologist, I am sufficiently senior to have been educated when the chemical and physical structure of the double helix, but little else, was known, and modern methods of biomolecular analysis were years from being developed. I suspect that I am not the only archaeologist in this situation. Even among younger age-sets of archaeological colleagues, those educated in British or Continental traditions may have had their last serious biology course in secondary school, while those in North America might have had a brush with late twentieth-century genetics as part of "general education" 
requirements for university undergraduates. Whenever I teach my course on the origins of farming, it is humbling to realize that even the cultural anthropology undergraduates can rattle off the basics of DNA and RNA chemical structure with more facility than I can. Thus, we archaeologists of the "old school" may feel ourselves not particularly well equipped for plunging into the technicalities of genetic studies. However, colleagues in Europe, South and East Asia have seen the relevance of forging a closer alliance with geneticists and of learning enough contemporary genetics to communicate effectively; for this effort, they have reaped great returns.

This introduction makes the case for the value of domestic animal genetics in elucidating essentially archaeological questions. It cites reasons why Africanists working with Holocene sites may have been slower to incorporate livestock genetic information than colleagues in Eurasia and discusses domestication as simultaneously a social and coevolutionary relationship. It makes no attempt to define domestication, an extensive and contentious topic in itself, and interested readers are referred to Zeder (2012) and Russell (2012). It does provide examples of how humans as well as animals have undergone evolutionary pressures in this unique relationship. It then outlines the research questions and approaches amenable to collaborations between archaeologists and geneticists. It ends by briefly introducing the papers, which outline genetics and archaeogenetics (Campana et al. 2013) and which present the current state of knowledge on five species: pig (Amils et al. 2013), sheep (Muigai and Hanotte 2013), cattle (Stock and Gifford-Gonzalez 2013), donkey (Kimura et al. 2013), and chicken (Mwacharo et al. 2013).

Three notable absences are papers on goats (Capra hircus), dogs (Canis familiaris), and cats (Felis catus). Goats, widespread and adaptable small ruminants, merit extensive genetic study, as many suspect their resilience makes them a good first species for hunter-gatherers to incorporate into their still largely foraging lifeways, as reflected by Bushman livestock adoptions (e.g., Peters et al. 2010). Their flexible feeding habits make them especially suitable for a range of drier environments. They fend off tsetse bites many times more successfully than do cattle or sheep and have been used as "shock troops" to clear underbrush in tsetse-infested areas (Lamprey and Waller 1990). Archaeological evidence hints at several routes of entry of goats from Southwest Asia into northeastern Africa, but, with the exception of the Mediterranean littoral of North Africa, few studies of modern African goat genetics, much less their archaeogenetics, have been undertaken. Thus, consulting with experts, I concluded that not enough work was available to ask for a summary for this issue. For relatively current information on goats in Africa, see GiffordGonzalez and Hanotte (2011). With regard to dogs, a preliminary study of the ancient DNA (aDNA) of a small sample of archaeological canid remains from the Western Cape of South Africa has been published (Horsburgh 2008). However, research on canid aDNA identification is currently under revision and expansion (A. Horsburgh, personal communication 2012). It is anticipated that this work will complement that on the modern genetics of African dogs by Boyko et al. (2009) and on living breeds (e.g., Hall 2000). Domestic cats in Africa, outside of their renowned place in Dynastic Egypt (Clutton-Brock 2012), are poorly documented. However, recent comprehensive genetic sampling of wild and domestic small cats indicates that cats underwent domestication throughout a broad range of the Levant and Arabia, as many as five distinct times, rather than in Africa (O'Brien et al. 2008). Wild cats were probably 
attracted to rodents and small birds parasitizing stored grains in early farming settlements, in multiple places and times, following what Zeder (2012) terms a commensal pathway into domestication, with taming occurring only after coexistence in proximity. For more details, see Gifford-Gonzalez and Hanotte (2011).

\section{The DNA Revolution}

Collaborations in Eurasia and the Americas among archaeologists, geneticists of modern breeds, and archaeogeneticists (geneticists specializing in ancient DNA, see Campana et al. 2013) have revolutionized the social and economic histories of food production. Among new findings is the recognition that pigs, goats, sheep, horses, and chicken underwent multiple domestications from local populations of wild ancestral species and that this pattern may be the norm rather than the exception.

Genetic research has sometimes provided unexpected evidence for shifts in animal breeds and more extensive trading relations than previously assumed. A striking example is pig domestication in Europe, where ancient DNA has significantly revised traditional archaeological narratives and favored one route of agricultural entry into Europe over another. Pigs are omnivores with high reproductive rates, sorting behaviorally more with dogs and humans than with ruminants, which may have enhanced their early contact with and manipulation by humans (Zeder 2012). The wild ancestors of domestic pigs were widespread across Europe, North Africa, Southwest, Central, East, and Southeast Asia. Genetic analyses have shown at least and six, possibly ten, local domestications from regional populations across this range (Larson et al. 2005, 2010). One of these domestications took place between 11,000 and 13,000 $\mathrm{BC}$ in the classic Near Eastern Neolithic, and both archaeologists and geneticists initially assumed that European domestic swine descended from animals introduced from there.

However, modern European domestic pigs uniformly lack Southwest Asian genetic signatures, instead displaying a mix of native European and East Asian haplotypes, the latter being the product of documented "breed improvement" in the eighteenth and early nineteenth centuries (Giuffra et al. 2000). This absence of Southwest Asian genetic heritage in modern European swine posed a question addressed by subsequent archaeological sampling, dating, and archaeogenetics. The oldest domestic pig bones in Europe, sixth-fifth millennium $\mathrm{BC}$ specimens from Romanian and northern German Linear Bandkeramik sites, do indeed display a Southwest Asian genetic signature, as would be expected of the species introduced into Europe as part of a Neolithic "package" (Larson et al. 2007). Their spatiotemporal pattern also supports the Danube-Rhine drainages as the primary route of entry for Near Eastern domesticates into Europe, rather than significant diffusion from the Mediterranean coasts (Larson et al. 2007).

Yet a millennium later, some sites testify to the emergence of indigenous pig domestication, as at the early fourth-millennium Paris Basin site of Bercy (Larson et al. 2007). Some Bercy pigs display Southwest Asian haplotypes, but others, identified on morphometric grounds as domestic, display haplotypes typical of European wild boar. Larson et al. (2007) note that, from the mid-fourth millennium onwards, all British Isle and Continental domestic swine sampled display European haplotypes, 
suggesting that the European stock increased from $5 \%$ to nearly $100 \%$ in less than 500 years.

Such a rapid and geographically extensive conversion to indigenous European stock implicates both biological and social processes. While their domestication suggests European swine's greater fitness in the ancestors' native environments, their rapid spread must reflect intensive human interaction at a continental scale. This in turn poses questions about the networks of communication and exchange in Neolithic Europe that facilitated this conversion, across what archaeologists have defined as major stylistic and technological boundaries.

The example of European pig domestication thus illustrates the relevance of genetic evidence to evaluating patterns of human migration, as well as its value in revealing hitherto obscure patterns of economic interaction. As suggested by the authors in this issue, parallel questions could be explored using the modern and ancient genetics of African livestock. In the African case, chicken, sheep, goat, and a significant proportion of African pig and cattle ancestors were introduced, with the last two species also having conspecifics in the northern part of the continent.

Compared with that in Europe, China, and Japan, genetic research on African livestock breeds is in its early stages. In Europe and East Asia, funding for describing the genomes of key economic species, driven by the aims of large-scale agricultural production, has also supported research on the genetic histories of those species (but also see Reynolds 2009). Research is impeded by relatively lower funding levels (see Amils et al. 2013), as well as the difficulty of accessing some regions due to poor infrastructure or political instability. Areas of difficult access include many Sahelian regions vital for tracing north-south and east-west movements of people, animals, and plants, as well as possible migration corridors for people and domesticates into southern Africa. Despite these handicaps, findings to date reveal important geographic patterns in the introduction and movement of distinct genetic lineages and indicate target regions for future sampling. Likewise, they suggest that archaeologists look more attentively toward remains of pig, small ruminant, and chicken, as well as those of more imposing cattle or equids, for candidates for ancient DNA analysis.

The interests of animal geneticists and archaeologists overlap but are not identical. Animal geneticists aim to learn more about the emergence of domesticated species, their places of origin, and histories of geographic spread, teasing out multiple independent transitions to domestication from other sources of diversity in genotypes. Now that entire species genomes of some species have been sequenced, geneticists can monitor which loci were under intense selective pressure in the domestication process and, in some cases, for which traits these loci code. By contrast, archaeologists, including zooarchaeologists, are ultimately interested in the human dimensions of domestication: its environmental, cultural, social, and economic contexts, as well as the effects that entering into such relationships with other species had on human societies.

This special issue shows where and how these interests overlap. Archaeogeneticists depend heavily upon archaeologists for the specimens they use to trace livestock history. All the discussions of livestock diversity in Africa by genetic specialists in this issue invoke processes embedded in the human social matrix. We can only mutually benefit by refining our knowledge of how each other thinks and practices - and by collaborating. A truly fine example of such collaboration in Africa is the case of donkey domestication (Kimura et al. 2011, 2013), where zooarchaeologists, animal behaviorists, geneticists of 
modern breeds, and archaeogeneticists worked together, also drawing on ethnoarchaeological documentation of the role of donkeys in pastoral societies as a way of thinking through the contexts of domestication (Marshall and Weissbrod 2010).

\section{The Lag in Africanist Engagement with Archaeogenetics}

Unlike their peers in Eurasia, Africanist archaeologists generally have been slower to board the now well-tuned vehicle of plant and animal genetics to elucidate human migration, cross-cultural exchange, and in-place domestication on the continent. Exceptions include the research team working on donkey domestication noted above, those contributing archaeological cattle specimens from the Sahara and Nile to a study of the sources of domestic cattle in Africa, Southwest Asia, and Europe (Edwards et al. 2004), and contributors of South African sheep and canid specimens for aDNA analysis (Horsburgh 2008; Horsburgh and Rhines 2010). As well, some have integrated archaeological information with human genetic and linguistic data to explore the nature of migration and adoption of food production in southern Africa (e.g., A. B. Smith 2011)

Several factors may influence Africanists' slower engagement with genetic research. The relatively lower levels of funding may mean that the African research environment as a whole is not as permeated by discussions of how archaeology and genetics can complement each other. The assumption that ancient DNA does not preserve in African archaeological environments may have also diminished archaeologists' motivations to explore animal genetics. In this issue, Campana et al. (2013) note that, although hot, dry environments indeed are not conducive to preservation of aDNA, some subtropical to tropical contexts, especially caves and high-altitude sites, may preserve it. Ancient DNA has been recovered from sub-fossil lemur remains in Madagascar (Campana et al. 2013), indicating its preservation potential in a tropical latitude region. Kimura et al. $(2011,2013)$ recovered aDNA from a specimen from Uan Muhaggiag, Libya. Although some parts of Southwest Asia share climatic characteristics with African regions, preservation problems have not forestalled the systematic search for recoverable aDNA there. The Mediterranean climates of far northern and southern Africa are demonstrably good environments for DNA preservation and recovery (e.g., Horsburgh 2008; Horsburgh and Rhines 2010).

However, some responsibility for a lack of engagement with plant and animal genetics resides, I believe, with the attitudes of Africanist archaeologists compared with those of colleagues elsewhere. Echoing Marshall (2000: 205-206), I suspect this lack of interest may stem from the viewpoint that animals, like plants, are "just biological" and therefore removed from interesting questions of human society and economy. Researchers living in societies where animals and plants are mass-produced under factory-like conditions, remote from the everyday lives of most people, may "naturally" focus on other signifiers of economic and social relations than animals. However, this is hardly the case for the majority of households in Africa, past or present. Herders, farmers, and even urban dwellers balance daily their household needs for animal products against their strategic potential for deployment as media of exchange, gifts, or religious sacrifice (Smith 2005). Thus, in most past societies, animals were foci of intense, socially grounded attention and economic manipulation, as necessary constituents of people's economic, social, and ritual lives. 
Moreover, even breed shifts are never "just biological." They reflect the shrewd assessments of animal condition, behavior, and productivity by people living in a social matrix where animals played a major economic role. From Mauss (1923 [2000]) onward, it has been a truism that the exchange of gifts simultaneously signifies benign intent and the establishment of reciprocal obligations. I would argue that domestic animal gifts go beyond the usual significations of exchanged inanimate objects. Bestowed animals usually produce offspring with conspecifics among the recipients' herds or flocks. Though not an exchange of human partners, such a "little marriage" of minor household members (Smith 2011) can be used as an avenue for instituting fictive kinship, albeit in a minor key. Formation of a quasi-familial bond forms the basis of extensive pastoral partnerships established by the gift or loans of animals (Arhem 1987; Dyson-Hudson and Dyson-Hudson 1970; Galaty and Bonte 1991; Gulliver 1955; McCabe 1990; Smith 2005).

Probably in reaction to its colonial history, perceptively explicated by Stahl (1999; see also Stahl 2004), Africanist archaeology continues to emphasize "origins" and "earliest appearances." This implicitly evolutionist trope views domestication as another invention, which, once realized, sheds little further light on the course of human history, except as a static item to be diffused from inventing to recipient groups. The case of European pigs shows that domestication is instead a continuous and often eventful process, which may encompass major changes long after its initial emergence (Gifford-Gonzalez and Hanotte 2011). A "first appearances" perspective overlooks major regional adaptations of people and domesticates to new circumstances. If, as genetic evidence now implies, maternal lineages of African cattle were Southwest Asian in origin (Stock and Gifford-Gonzalez 2013), this in no way diminishes the remarkable evolutionary history of the species in African environments. For example, the small cattle breeds of forested West Africa prosper as milk and meat providers despite sustaining infection with sleeping sickness, which kills other breeds (Aboagye et al. 1994). Ankole cattle of Central Africa bear imposing horns, initially seen as evidence of the irrationality of the African "cattle complex" (e.g., Herskovits 1926). While Ankole are prized for their appearance, researchers have shown that they survive and reproduce significantly better under the burden of endemic, tick-borne East Coast fever than do introduced breeds (Ocaido et al. 2009). The evolutionary histories of these breeds are necessarily entangled with those of their herders, whose lives depended, to one degree or another, upon their prudent management, and whose fortunes rose or fell upon the animals' resilience and productivity.

\section{Domestication as a Mutualist Relationship: Some Examples}

Although I have advanced an argument that domestication is not simply a biological process and that it always exists within a human social matrix, it does have biological and ecological dimensions. Over the last 15,000 years, humans and certain animal and plant species have entered into a relation that ecologists call mutualism. Mutualist species both benefit from their relation, sustaining higher population levels and broader geographic ranges than they did when not in this type of symbiosis, despite the "sacrifice" of individuals from one mutualist species to consumers in the other, as is the case with wheat or sheep. Zeder (2012) provides an excellent overview of the several pathways animals have taken into domestication. 
We humans usually conceive of domestication as animals adapting to us: As the dominant party in these relations, humans do structure the environments, daily routines, and, ultimately, the life histories of their domesticates. However, domestic species, especially animals, have reciprocally presented humans with novel selective pressures and occasionally opened new opportunities for evolutionary success. Such challenges include increased labor demands of sustaining domestic species, impacts of infectious agents that "jump species" from domesticate to human (zoonoses), and selection for human phenotypes that enhance the use of animal products. Examples of these three may be useful.

First, the greater the dependence of humans on a domestic species for their sustenance, either by directly subsisting on its products or by using its products to obtain other foods, the more energy that species may demand of their keepers for their survival. Pastoralists move to suit the forage and water requirements of their herds, shutting off other avenues of subsistence and imposing the stresses of mobility on all members of their populations (Dahl and Hjort 1976). In contemporary pastoral societies, reproductive-age women carry the heaviest workload, challenging successful childbearing and rearing upon which group survival ultimately depends (Aregu and Belete 2007; Bailey 2012; Marshall and Weissbrod 2010).

Second, zoonotic diseases have become such a routine part of our experience that we usually see them as normal, if potentially dangerous, aspects of human life. However, all, save tapeworms (Hoberg et al. 2001), developed after animal domestication. Cholera, smallpox, chicken pox, measles, brucellosis, and the more virulent, recently emerged viral infections such as H1N1 and SARS, all derive from domestic animal hosts. Researchers have also established that Streptococcus bovis, a bacterium of ruminant guts, causes endocarditis and a variant of neonatal meningitis in humans, and is possibly linked with colorectal cancer (Boleij et al. 2011; Ray and Ray 2004). Populations with longer selective histories of specific zoonotic diseases better tolerate infections by them, while groups lacking such histories suffer more virulent reactions upon exposure. The course of colonial encounters in the Americas and Africa were strongly affected by the divergent reactions among hitherto unexposed populations to zoonotic infections of Eurasian origin, especially smallpox.

Third, at least four mutations that favor the extended production of lactase, the enzyme that breaks down the milk sugar lactose, have been selected for in human populations that incorporated milk from domestic hoofed animals into their diets. Hoofed domesticates convert inedible grasses and leaves into meat and milk, and lactase persistence permits people of all ages to consume a product while not killing the producer. Although most publications stress the value of prolonged lactose digestion in adults, selection for the trait may have been especially intense among weaned children, who face major nutritional and immunological challenges in their transition from mother's milk to adult foods in many groups.

Among populations in Eurasia, lactase persistence ranges from $1 \%$ to $>90 \%$, correlating with the degree to which groups historically engaged in dairying, and the genetic basis of lactase persistence has been studied extensively. One mutation, the C/T-13910 SNP, inherited as a single, dominant Mendelian trait (Tishkoff et al. 2007), determines lactase persistence from Western Europe to East Asia.

In sub-Saharan African pastoralist populations, despite documented lactase persistence rates of $50 \%$ to $90 \%, \mathrm{C} / \mathrm{T}-13910 \mathrm{SNP}$ occurs rarely and in relatively low 
frequencies $(<14 \%)$ in the Sahelian populations historically involved in the transSaharan trade, notably Fulfulde-speakers and Hausa (Tishkoff et al. 2007). Significantly, Fulbe people show 50 \% lactase persistence, despite their much lower rate of occurrence of C/T-13910 (McIntosh and Scheinfeldt 2012; Tishkoff et al. 2007).

To explore whether Africa had seen a convergent evolution of other genetic loci contributing to lactase persistence, Tishkoff et al. (2007) sampled East African populations from Sudan, Kenya, and Tanzania with varied rates of observable lactose digestion in adults. They found three Africa-based mutations (G/C-13907, T/G13915, and C/G-14010), which, they established experimentally, extend lactase production. They highlight the C-14010 SNP, which occurs at high frequencies in speakers of Nilo-Saharan and Afro-Asiatic languages. Using average mutation rates, Tishkoff et al. (2007:198) estimate origination of the C/G-14010 SNP around 6,000$7,000 \mathrm{BP}(95 \%$ confidence interval 2,000-16,000 BP). This range accords with the first appearance of processed milk lipids in ceramics from the Acacus, Libya sequence, radiocarbon dated to c. 7,500 BP (Dunne et al. 2012). Nilo-Saharan and Afro-Asiatic languages are thought to have their origins in the Sahara-Sahel, later expanding into Central and East Africa (Ehret 1993). Ehret (e.g., 1993, 1995, 2008) has long contended that the existence of Afro-Asiatic loan words for milking and animal keeping in Nilo-Saharan and Niger-Congo languages argues for the origination of dairying in the Saharan regions formerly inhabited by Afro-Asiatic speakers. Convergence of these lines of evidence in the seventh-eighth millennia BP strongly suggests an independent trajectory into dairying and the diversity of loci hints at selection for lactase persistence in more than one African population from that time onward.

\section{Bases for Collaborative Research: Modern and Ancient DNA}

Two classes of genetic data can serve as bases for collaborative research between archaeologists and geneticists: modern DNA and ancient DNA. In this issue, Campana et al. (2013) introduce the terms and type of genetic materials most commonly used in such research, and here, I will simply touch on their general parameters. Research based on modern DNA, especially at the whole genome level, has revealed many specific loci selected for during the domestication process and, thus, elucidates the process (Rubin et al. 2010). However, modern DNA research has two weaknesses for those interested in the history of species or breeds. First, it only can summarize a species' extant genetic variability, possibly giving an incomplete view of past genetic diversity, since aDNA has established that some species' lineages have been lost over time. Second, given the uncertainties in species- or gene-specific rates of mutation, so-called molecular clocks optimally require some independent calibration (e.g., Kumar 2005).

Despite modern animal genetics' great advantages over traditional archaeological methods for exploring species' domestication histories, there may be limits to what can be inferred from living lineages. Larson et al. (2012) undertook a comprehensive analysis of autosomal single-nucleotide polymorphisms (SNPs) of living dog lineages (1,375 dogs of 35 breeds, 19 wolves, plus results of other, previous, canid SNP sampling projects), constructing a neighbor-joining phylogenetic tree from the degrees of genetic resemblance and divergence. They argue that their results challenge 
previous assumptions regarding the "ancient" status of breeds that lie at basal positions in such trees, as constructed from modern samples. First, they note that the basenji (Africa), dingo (Australia), and New Guinea singing dog, all of which lie in basal positions in multiple SNP phylogenies, are from regions outside the native ranges of wolves, the acknowledged ancestor of all dogs. In all three cases, archaeological evidence indicates these dogs were introduced into their regions as much as 10,000 years after initial archaeological evidence for domesticated dogs. Given these facts, the authors recommend referring to all such breeds as "basal" rather than "ancient." Second, they note that the most ancient archaeological dog specimens are not found in the locales of modern basal breeds, as inferred from modern DNA. They conclude that what unifies these basal breeds is not necessarily truly "ancient" status but a "lack of recent admixture with other breeds likely facilitated by geographic and cultural isolation" (Larson et al. 2012:8878). Dogs' great potential mobility with migrating humans, combined with their high rates of interbreeding, has thus overprinted and obscured regionally distinctive genetic patterns that might reveal original areas of domestication. The authors conclude that these findings should prompt a rethinking of the utility of modern DNA for isolating the location and number of domestication events. They argue that human genetic studies can serve as a guide, where a combination of whole-genome analysis of modern and ancient DNA, plus high-input analysis of millions of, rather than a few thousand of, markers have revealed more complex regional histories and interbreeding. Larson et al. (2012) contend that a parallel approach with modern and ancient DNA should produce deeper insights into the histories of various domesticated species. The study thus underlines both the importance of aDNA and of viewing our present understandings from modern DNA as a sketch, rather than a final definition, of domestication trajectories.

Ancient DNA can offset the weaknesses of modern population sampling. It has revealed the possible contribution of extinct wild populations to the modern domesticates' gene pools and past diversity in domestic stock subsequently lost over their breeding history (Fernández et al. 2006). In the case of Africa, it has established the existence of a hitherto unknown, albeit recently extinct, wild ass population in East Africa (Kimura et al. 2011). However, aDNA researchers must contend with degradation of nucleic acid in bone, teeth, and eggshell over time, which limits the quantity and quality of recoverable DNA segments. Archaeogeneticists have also learned from bitter experience that bacterial, fungal, and modern animal DNA can contaminate material extracted from archaeological and paleontological specimens (Campana et al. 2013).

\section{Questions for Collaborative Research: Reframing and Refocusing}

One can fairly ask what range of questions collaborative research between archaeologists and geneticists can address, and how. Some issues are of course beyond the purview of genetic research whether plant, livestock, or human. Metallurgical research, for example, will likely gain nothing immediate from it. Even if we prove that chicken breeds originally domesticated in Myanmar/Yunnan show up in southern Africa, for many the response is, "So what?" It is up to archaeologists to respond to that question by mobilizing archaeological theory and method. This section suggests some ways to approach such research. 
Surveying the accomplishments of animal genetics elsewhere, as well as those reported in this issue, suggests that genetic data can inform on two different geographic scales relevant to archaeological research on human interactions and social change. Additionally, the presence of domesticates from a specified region can be combined with other independent lines of evidence to explore the nature of interactions between or among regions, subcontinental and intercontinental.

To date, the most common approach uses regionally distinctive haplogroups, either in modern or ancient DNA, to trace the human migrations and/or exchange networks that moved animals and plants on a geographically extensive scale. While geneticists can document the spread of a particular haplogroup from its wild ancestors' home range, determining whether this was the product of human migration or of intergroup exchange is the province of archaeology. Though sometimes aided by human genetics, such judgments are usually based upon a reading of regional distinctions among settlements, architecture, artifacts, and other stylistic evidence, as well as assessment of other evidence for exchange in the groups assumed to have been transferring domesticates. For archaeologists in the twenty-first century, this process should be more circumspect than a classic culture-historic explanation of migration $v s$. diffusion, invoking the now extensive but still contentious global literature on population movements and exchange systems and how they play out at local levels (Stahl 2002; Lightfoot 2005).

A second, smaller-scale focus is possible: monitoring local or regional changes in breed characteristics over time, using aDNA as a complement to classic osteological analysis. This area of research is less developed, even in Europe, perhaps less due to a lack of archaeological specimens than to their as-yet patchy accessibility for the modest form of destructive testing involved in aDNA sampling. Thus far, most studies of changes in breed characters have been geographically broad, as with documentation of horse-coat color diversification over several thousand years (Ludwig et al. 2009). However, one can imagine aDNA studies from large, deeply stratified sites or clusters of well-dated sites that reflect shifting local choices for certain breed characteristics over time.

This would permit development of a "cartography of taste" for animal introductions, to use a phrase applied by Stahl (2002), not just for the colonial time frame but for that longer span over which domestic plants and animals were incorporated into African societies. Such a project, based on collaboration with archaeogeneticists, modern geneticists, and probably linguists and ethnohistorians, is an eminently archaeological grounded endeavor, theoretically and methodologically.

Stahl $(2004,2002)$ discussed the concepts of taste and embodied practice as an alternative to a focus on meaning in archaeology. There is much more to her argument, which aligns with Bourdieu's (2000[1997]) and others' critique of the overemphasis on language as an explicatory model. Here, I focus on Stahl's advocacy of taste and embodied practice as they relate to archaeologically recoverable materials. These concepts have a significant literature in social and cultural studies and are, because the concrete results of choice can be seen materially, archaeologically applicable. Stahl explored how certain artifacts in Banda, Ghana-spindle whorls, tobacco pipes, beads - indicate local and regional shifts in taste and practice, with changes in subcontinental and transcontinental engagements over the precolonial and colonial time span. 
I believe Stahl's approach, with some modifications, can serve those of us who study the human dimensions of animal adoptions in Africa. The observable patterns of choice in adopting nonlocal species or breeds reflect a winnowing of breed characters at the household level, which may show up in domestic animal (and plant) aDNA. Where I would modify Stahl's approach is to argue that, in contrast to taste and embodied practice as it affects the artifacts she discusses, choice of animals and plants is strongly driven by considerations of efficiency. I mean here not the abstract efficiency of deterministic processual modeling, but the household manager's day-today assessment of marginal gains in time or nutrients that a new species, breed, or strain offers. Quotidian agricultural and pastoral workload falls most heavily on reproductive-age women, who also, in nearly all known cases, manage food resources at the household level, even among strongly patriarchal cultures (Aregu and Belete 2007; Bailey 2012; Barker et al. 2006; Lukmanji 1992). More tractable, productive, or readily processed domesticate varieties realize gains in a household manager's finite time and energy budget, immediately measureable as more freed-up time. Over a longer but evaluable span, another measure is the overall condition of children, who, as every modern famine shows us, swiftly manifest improving or worsening nutritional levels physically. Thus, I argue that taste and embodied practice with regard to new types of animals or plants are intimately tied to assessments of marginal gains in physical welfare and time budgets by knowledgeable actors well versed in minute, quotidian trade-offs of time and energy.

The rapid replacement of guinea fowl by chicken in West African urban settlements and villages may reflect such assessments. MacDonald $(1992,1995)$ read this transition as both a choice of a more behaviorally suitable species for household use than the notoriously flighty native guinea fowl and a manipulation of an imported species in the late first and early second millennia AD by emerging elites. I would add that, especially in urbanizing contexts, chicken would quickly reveal their practical superiority. Like guinea fowl, chickens can sustain themselves by foraging on their own yet, unlike guinea fowl, they usually return to their owners' homesteads to roost and lay their eggs. They outperform hoofed ruminants four-to-one in forage-to-meat conversion, as well as providing eggs, which, like milk, are obtained without killing the producer (Gifford-Gonzalez and Hanotte 2011). They forage in gardens for insect pests and, like guinea fowl, will consume ticks in livestock pens. Their widespread adoption and relatively high status in African food systems reflects indigenous assessment of all their traits, practical as well as symbolic.

Finally, even if archaeologists are not personally entranced with the histories of regional livestock, those investigating the scale and nature of subcontinental and transcontinental trade can benefit from encouraging the study of animal and plant genetics. Commercial relationships usually incorporate multiple commodities moving in either direction. Trade involving beads, cloth, salt, foodstuffs, metal artifacts, and a host of other inanimate products may also implicate plants and animals. The confirmed appearance of African sorghum, pearl millet, cow pea, and hyacinth bean in South Asia by 3,300-4,000 BP indicates that exchange along the shores of the Indian Ocean, probably facilitated by residents of the Arabian Peninsula, was strong long before the Islamic era (Boivin and Fuller 2009). Typological description and sourcing of trade beads found in Africa is still under development (e.g., Insoll et al. 2004; Popelka et al. 2005; Wood 2011). However, beads, metal artifacts, ceramics traceable 
to sources, along with "sourced" and dated animal and plant haplogroups, can indicate the number of phases of contact between areas, whether certain items came as a "package," or whether plants, animals, and artifactual products were "repackaged" by middlemen along subcontinental and transcontinental trading routes. In such an application, domesticates are just one of an array of multiple lines of independent evidence, but an important one.

\section{Papers in this Issue}

The articles in this issue largely speak for themselves, but a few points merit emphasis. I asked these experts in genetics to convey findings from their fields, not to summarize all that is known historically, archaeologically, and linguistically about the domestication of the species they study. It would have been unfair to ask them to sufficiently master another academic discipline, namely archaeology, to do so. Summaries that touch on these topics include Blench and MacDonald (2000) and, to an extent, Gifford-Gonzalez and Hanotte (2011) and Clutton-Brock (2000, 2012). One exception to this is the article on cattle, a species over which so much ink has been spilled that a somewhat more extensive treatment of the archaeological literature is merited. Rather than saddle the senior author with the equivalent of earning an advanced degree in archaeology, I volunteered to supply that part of the paper. The following remarks highlight implications of topics presented in the articles.

DNA for the Archaeologist

Campana et al. (2013) supply a sound introduction to the basics of DNA analysis and offer advice for archaeologists who wish to enter collaborations with archaeogeneticists. For clear and detailed examples of the uses of mtDNA and autosomal DNA, readers may wish to consult McIntosh and Scheinfeldt's (2012) article in a recent issue of the African Archaeological Review.

Campana et al.'s (2013) key advice is that the optimal prescription for aDNA research is for archaeologists and archaeogenetics researchers to establish relationships beforehand, assessing the potential of target archaeological sites to preserve DNA and mutually defining research problems that aDNA analysis can elucidate. Campana et al. (2013) note that some archaeogeneticists prefer to recover specimens in the field themselves. Rather than an imposition on fieldwork routine, their presence should be an opportunity, as we archaeologists all know that relaxed conversations in the field are often the context for new ideas and collaborations.

Moreover, archaeologists may also be well placed to help geneticists of modern domestic animal populations gain access to a broader array of DNA samples. Several papers in this issue remark on the paucity of modern livestock samples from certain African regions, where expense and lack of infrastructure limit access by geneticists. Especially in such remote areas, archaeological field camps could host genetics researchers, providing not only a place to stay while collecting local samples but also using archaeologists' established relationships with local farmers or herders to facilitate sample collection. 
Pig

Amils et al. (2013) report on the long history of swine in West and East Africa, the latter hinting at introduction from East Asia before European incursions into the region. This is probably news to most archaeologists, who may have assumed that the Islamic practices of Swahili traders would have forestalled any such introduction in the thriving Indian Ocean exchanges of the early to mid-second millennium AD. However, the Indian Ocean trade antedates Islam considerably, and even during the apogee of Swahili stone towns, many coastal dwellers were not Muslim, nor were people in the hinterlands. This genetic information should warn archaeologists to conserve pig bones whenever found in those regions, rather than assume they are stratigraphically intrusive elements from European colonial times, and to contact genetic researchers on the species.

Amils et al. (2013) also report on the need to preserve indigenous lines of pigs, which are being replaced by or crossbred with exotic breeds. Sadly, this repeats nowacknowledged errors of exotic cattle breed introductions, which proved to be less resilient over the long term than the "inferior" local breeds they replaced. The authors stress that, although exotics may have better growth and reproductive performance, local breeds have more staying power in the face of disease challenges, which is probably genetically based. Any archaeologist doing fieldwork in Africa knows that the vast majority of African people depend upon domestic species that must withstand the rigors of their environments away from the coddling and care of agricultural research stations. African farmers and pastoralists possess indigenous veterinary knowledge and skills, as well as willingness to take up new techniques that help their livestock (e.g., Ocaido et al. 2009). Presenting them with "productive" but fragile foreign breeds does them a disservice.

\section{Sheep}

Muigai and Hanotte (2013) report on the state of modern mtDNA analysis of African sheep. They report the mtDNA of African fat-tailed varieties nearly exclusively falls within haplogroup A, one of the two most common sheep haplogroups, whereas thintailed African sheep are typified by haplogroup B. The sole exception is one North African fat-tailed hair sheep breed, the Ossimi, which groups genetically with thintailed West African sheep. They account for this as the result of introduction of fattailed stock into pre-existing thin-tailed sheep populations of northern Africa. These preliminary results suggest a palimpsest of introductions at the intracontinental level, at least in northern Africa. Sheep of some regions, including the Congo Basin and Angola, are at present poorly sampled, which, because this region is one of the proposed corridors for movement of sheep into southern Africa, must be remedied.

Horsburgh and Rhines (2010), analyzing aDNA of 20 sheep specimens derived from sites on the Western Cape of South Africa, found them to be exclusively of Clade B, suggesting they were likely thin-tailed but perhaps again reflecting another palimpsest of introductions in the region. The close relationship Muigai and Hanotte (2013) found between the Newala, one of several Tanzanian fat-tailed sheep breeds, and southern African fat-tailed sheep is of interest to archaeologists concerned with the route(s) of livestock introduction into southern Africa. This finding accords with a proposal by human geneticists Henn et al. (2008), of a pre-Bantu, pastoralist 
migration, at least by males originating in Tanzanian populations, ultimately to Angola and Namibia, based upon high frequencies of a unique Y-chromosome haplogroup in both areas. The E3b1f-M293 haplogroup is a variant in the more broadly distributed E3b1-M35* clade common in East and Central African human populations. M293 frequencies are highest in two Tanzanian groups, the Datog (Nilo-Saharan language group, present-day pastoralists) and the Burunge (Afro-Asiatic language group, presentday agropastoralists), and among the Khwe (a.k.a. Kxoe, of the Khoe branch of Khoisan language group) of Namibia. Angola !Kung populations showed somewhat lower M293 frequencies. Clearly, further genetic sampling of both human Y-chromosome and mtDNA and of sheep populations along this $3,700 \mathrm{~km}$ transect is merited, as well as realistic models for a moving front of pastoralists sustaining its integrity in some way during this spread (Smith 2005).

Cattle

In this co-authored piece, Stock and Gifford-Gonzalez (2013) report on very recent findings from modern and aDNA that indicate the mitochondrial lineage of Africa taurine cattle may derive from Southwest Asia. This is a reversal of earlier inferences by the Trinity College, Dublin research team responsible for early work on modern African cattle genetics. Stock's doctoral training was with the Trinity College team, so her findings are not so much a contradiction as a modification of earlier inferences drawn before full genomic sequencing of cattle was complete. At the same time, evidence does exist for the introgression of a diverse set of Y-chromosome haplotypes, which at least some scientists see as probably derived from the now-extinct wild cattle of northern Africa (Pérez-Pardal et al. 2010). Yet, as the text outlines, debate still goes on.

\section{Donkey}

Kimura et al. (2013) relate the discovery through aDNA of a hitherto unknown East African wild ass population that contributed to today's domestic donkeys. Such an archaeologically unattested instance was termed a "cryptic domestication" by Larson et al. (2010), whose major review of modern and ancient DNA from wild and domestic pigs in South, Southeast, and East Asia revealed that the DNA of domestic pigs from India and mainland Southeast Asia displays evidence for four hitherto undocumented domestications from regional wild boar populations.

With its combination of zooarchaeology, ethnographic information, modern genetics, and archaeogenetics, the Kimura et al. (2011, 2013) article is a model for collaborative and mutually supportive research.

\section{Chicken}

The varied histories of chicken lineages in Africa may be especially valuable to tracing early commercial connections across the Indian Ocean and through Nilotic and Sahelian worlds. The chicken is a hardy creature: Even today, newly hatched chicks are posted through the mails of some developed countries. They are light, portable, and tolerate being caged, even producing eggs under the right circumstances. Thus, they travel well 
with people versed in their needs and behavior. In this issue, Mwacharo et al. (2013) suggest that multiple lineages of South Asian and Southeast Asian domestic chickenincluding two relatively rare ones - followed several different paths of entry into Africa, which in turn may reflect divergent, sometimes temporally successive, systems of commercial contact.

The presence of haplogroup A in Madagascar as well as eastern and southern Africa presents an interesting case of cultural interaction and change that calls for further collaborative research. As Mwacharo et al. (2013) note, this chicken haplogroup is most diverse in Indonesia, the original home of seafaring migrants who settled Madagascar in the mid-first millennium AD. One would expect that these migrants carried chickens with them, as well as other typically Southeast Asian crops such as rice and banana, yet the authors report the Malagasy word for chicken is of Bantu origin (Blench 2006). This poses a cultural and social puzzle, as the dominant language of Madagascar is Borneo-derived and elite practices are more Indonesian than African (see also Blench 2007). Moreover, historically documented cultural practices in what is now Indonesia, and especially on Borneo, foreground cockfighting as a major ritual. One might therefore assume that ritual as well as economic considerations would prompt mid-first millennium Austronesian migrants to carry chicken stock with them if this ritual complex emerged in Borneo by then. Recent genetic research by Hurles et al. (2005) indicates that the Malagasy population is almost equally African and Indonesian both in maternal and paternal genetic heritage. Interactions of these two populations, and the entangled history of chickens, thus may have been quite complex over the late first and early second millennia $\mathrm{AD}$, and merit further investigations involving linguists as well as archaeologists and geneticists.

The distribution of haplogroup E in eastern and western Africa is, as the authors note, of considerable interest because this lineage reveals another nexus of interaction than the Indonesia-mediated dispersal of haplogroup A, its genetic affinities instead implying transshipment via Sri Lanka, as well as the overland routes suggested for haplogroup D. Haplogroup F, of geographically restricted origin in the Myanmar-south Yunnan region, was found by Mwacharo et al. (2013) in one animal from Botswana. The fighting cocks of Indonesia, China, and Japan share haplogroup F, and the authors' suggestion that this lineage may have been imported during the height of the Indian Ocean trade with successive African polities such as Mapungubwe and Mutapa should motivate closer study of chicken remains from around these centers. Given the low relative proportions of both haplogroups $\mathrm{E}$ and $\mathrm{F}$ in global chicken populations, it is unlikely that both would have got to Africa strictly by random sampling. This suggests that entrepreneurs involved in trading chicken stocks across the Indian Ocean may have targeted them due to their physical or behavioral characteristics.

\section{Opportunities for Future Collaborations}

Ultimately, the presence of domestic animals is evidence of relationships: animal-to-human and human-to-human. Animals are fostered and become part of food production systems through human oversight and often very close physical relations with humans, who may consider them as minor family members. They spread along the relationships that people have with relatives, 
friends, and trading partners, be they neighbors, shoppers at the local market, quartermasters (or mistresses) from the palace, or exotic entrepreneurs from faraway places.

Africanist archaeologists who understand the relevance of local breeds and their genetics to tracing the intertwined histories of humans and domesticates in evolving landscapes could thus facilitate a fuller historical view of their introductions. Presently, no clearinghouse exists for archaeologists and geneticists to post their planned fieldwork sessions, which could create a greater research synergy. One can envision postings to websites of the Society of Africanist Archaeologists, the International Livestock Research Institute, Nairobi, or other organizations, as a way of facilitating such international cooperation.

Domestic animals' continued coevolution with humans in urban and complex societies, and their resultant genomes, can offer a vast amount of historical information that may be especially relevant to modern African communities dealing with social and environmental changes. Taking their histories and cultural, social, and economic roles seriously in our archaeological research is thus pertinent not only to the past but also to the future of people in Africa.

Acknowledgments I am indebted to a number of people for their encouragement and support during the formulation and production of this issue. The session that motivated this collection of papers was made possible by Professor Peter Breunig's excellent team, who organized the 2008 Frankfurt Meeting of the Society of Africanist Archaeologists. I am grateful to all the anonymous reviewers who offered feedback to the authors of the issue's articles. Dan Bradley, Fiona Marshall, Andy Smith, and Olivier Hanotte have all provided help and advice without which this issue could not have come to fruition. African Archaeological Review Editor Adria LaViolette has been a constant good counsel through the process.

\section{References}

Aboagye, G. S., Tawah, C. L., \& Rege, J. E. O. (1994). Shorthorn cattle of west and central Africa III. Physical, adaptive and special genetic characteristics. http://www.fao.org/docrep/T1300T/ t1300t0a.htm. Accessed 30 November, 2009.

Amils, M., Ramírez, O., Galman-Omitogun, O., \& Clop, A. (2013). Domestic pigs in Africa. African Archaeological Review, 30(1).

Aregu, L., \& Belete, Y. (2007). Coping with drought in the Borana rangelands. In: A. Ridgewell, G. Mamo, \& F. Flintan (eds.), Gender and pastoralism, vol. 1: Rangeland and resource management in Ethiopia (vol. 1). Addis Ababa: SOS Sahel Ethiopia.

Arhem, K. (1987). The symbolic world of the Maasai homestead. Rev. version (vol. no. 10, Working Papers in African Studies). Uppsala, Sweden: African Studies Programme, Department of Cultural Anthropology, University of Uppsala.

Bailey, J. (2012). Gender dimensions of drought and pastoral mobility among the Maasai. Africa Portal Backgrounders, 22.

Barker, M., Chorghade, G., Crozier, S., Leary, S., \& Fall, C. (2006). Socio-economic factors, lifestyle and gender differences in body mass index in rural India. Journal of Nutrition, 136(12), 3062-3068.

Blench, R. M. (2006). Archaeology, language, and the African past. Lanham, MD: Altamira Press.

Blench, R. M. (2007). New palaeozoogeographical evidence for the settlement of Madagascar. Azania: Archaeological Research in Africa, 42(1), 69-82.

Blench, R. M., \& MacDonald, K. C. (Eds.). (2000). The origins and development of African livestock. Archaeology, genetics, linguistics, and ethnography. London: UCL Press. 
Boivin, N., \& Fuller, D. Q. (2009). Shell middens, ships and seeds: Exploring coastal subsistence, maritime trade and the dispersal of domesticates in and around the ancient Arabian Peninsula. Journal of World Prehistory, 22, 113-180.

Boleij, A., van Gelder, M. M., Swinkels, D. W., \& Tjalsma, H. (2011). Clinical importance of Streptococcus gallolyticus infection among colorectal cancer patients: Systematic review and metaanalysis. Clinical Infectious Diseases, 53(9), 870-878.

Bourdieu, P. (2000[1997]). Pascalian meditations (R. Nice, trans.). Stanford: Stanford University Press.

Boyko, A. R., Boyko, R. H., Boyko, C. M., Parker, H. G., Castelhano, M., Corey, L., et al. (2009). Complex population structure in African village dogs and its implications for inferring dog domestication history. Proceedings of the National Academy of Science, 13903-13908.

Campana, M. G., Bower, M. A., \& Crabtree, P. J. (2013). Ancient DNA for the archaeologist: The future of African research. African Archaeological Review, 30(1).

Clutton-Brock, J. (2000). Cattle, sheep, and goats. In R. M. Blench \& K. C. MacDonald (Eds.), The origins and development of African livestock: Archaeology, genetics, linguistics, and ethnography (pp. 30-37). London: UCL Press.

Clutton-Brock, J. (2012). Animals as domesticates: A world view through history. East Lansing, MI: Michigan State University Press.

Dahl, G., \& Hjort, A. (1976). Having herds. Pastoral herd growth and household economy (Vol. no. 2, Stockholm Studies in Social Anthropology). Stockholm, Sweden: Department of Anthropology, University of Stockholm.

Dunne, J., Evershed, R. P., Salque, M., Cramp, L., Bruni, S., Ryan, K., et al. (2012). First dairying in green Saharan Africa in the fifth millennium BC. Nature, 486, 390-394.

Dyson-Hudson, R., \& Dyson-Hudson, N. (1970). The food production system of a semi-nomadic society: The Karimojong, Uganda. In P. F. M. McLoughlin (Ed.), African food production systems: Cases and theory (pp. 91-124). Baltimore: Johns Hopkins Press.

Edwards, C. J., MacHugh, D. E., Dobney, K. M., Martin, L., Russell, N., Horwitz, L. K., et al. (2004). Ancient DNA analysis of 101 cattle remains: Limits and prospects. Journal of Archaeological Science, 31(6), 695-710.

Ehret, C. (1993). Nilo-Saharans and the Saharo-Sudanese Neolithic. In T. Shaw, P. Sinclair, B. Andah, \& A. Okpoko (Eds.), The archaeology of Africa: Foods, metals, and towns (pp. 104-116). London: Routledge.

Ehret, C. (1995). Reconstructing Proto-Afroasiatic (Proto-Afrasian): Vowels, tone, consonants, and vocabulary (vol. 26, University of California Publications in Linguistics). Berkeley: University of California Press.

Ehret, C. (2008). The early livestock-raisers of southern Africa. Southern African Humanities, 20, 7-35.

Fernández, H., Hughes, S., Vigne, J.-D., Helmer, D., Hodgins, G., Miquel, C., et al. (2006). Divergent mtDNA lineages of goats in an Early Neolithic site, far from the initial domestication areas. Proceedings of the National Academy of Science, 103, 15375-15379.

Galaty, J. G., \& Bonte, P. (Eds.). (1991). Herds, warriors, and traders: Pastoralism in Africa. Boulder, CO: Westview Press.

Gifford-Gonzalez, D., \& Hanotte, O. (2011). Domesticating animals in Africa: Implications of genetic and archaeological findings. Journal of World Prehistory, 24(1), 1-23.

Giuffra, E., Kijas, J. M., Amarger, V., Carlborg, O., Jeon, J. T., \& Andersson, L. (2000). The origin of the domestic pig: Independent domestication and subsequent introgression. Genetics, 154(4), 1785-1791.

Gulliver, P. H. (1955). The family herds: A study of two pastoral tribes in East Africa, the Jie and Turkana. (International Library of Sociology and Social Reconstruction). London: Routledge \& Kegan Paul.

Hall, S. (2000). The origins and development of African livestock. Archaeology, genetics, linguistics, and ethnography. In R. M. Blench \& K. C. MacDonald (Eds.), Indigenous domesticated dogs of southern Africa: An introduction (pp. 302-311). London: UCL Press.

Henn, B. M., Gignoux, C., Lin, A. A., Oefner, P. J., Shen, P., Scozzari, R., et al. (2008). Y-chromosomal evidence of a pastoralist migration through Tanzania to southern Africa. Proceedings of the National Academy of Science, 105(31), 10693-11069.

Herskovits, M. J. (1926). The cattle complex in East Africa. American Anthropologist, 28, 230-272.

Hoberg, E. P., Alkire, N. L., Queiroz, A. D., \& Jones, A. (2001). Out of Africa: Origins of the Taenia tapeworms in humans. Proceedings of the Royal Society of London. Biological Sciences, 268(1469), 781-787.

Horsburgh, K. A. (2008). Wild or domesticated? An ancient DNA approach to canid species identification in South Africa's Western Cape Province. Journal of Archaeological Science, 35, 1474-1480. 
Horsburgh, K. A., \& Rhines, A. (2010). Genetic characterization of an archaeological sheep assemblage from South Africa's Western Cape. Journal of Archaeological Science, 37(11), 2906-2910.

Hurles, M. E., Sykes, B. C., Jobling, M. A., \& Forster, P. (2005). The dual origin of the Malagasy in Island Southeast Asia and East Africa: Evidence from maternal and paternal lineages. American Journal of Human Genetics, 76, 894-890.

Insoll, T., Polyab, D. A., Bhanc, K., Irving, D., \& Jarvise, K. (2004). Towards an understanding of the carnelian bead trade from Western India to sub-Saharan Africa: The application of UV-LA-ICP-MS to carnelian from Gujarat, India, and West Africa. Journal of Archaeological Science, 31(8), 1161-1173.

Kimura, B., Marshall, F. B., Chen, S., Rosenbom, S., Moehlman, P. D., Tuross, N., et al. (2011). Ancient DNA from Nubian and Somali wild ass provides insights into donkey ancestry and domestication. Proceedings of the Royal Society B. doi:10.1098/rspb.2010.0708.

Kimura, B., Marshall, F., Beja-Pereira, A., \& Mulligan, C. (2013). Donkey domestication. African Archaeological Review, 30(1).

Kumar, S. (2005). Molecular clocks: Four decades of evolution. Nature Review Genetics, 6, 654-662.

Lamprey, H. F., \& Waller, R. (1990). The Loita-Mara region in historical times: Patterns of subsistence, settlement and ecological change. In P. T. Robertshaw (Ed.), Early pastoralists of South-Western Kenya (pp. 16-35). Nairobi: British Institute in Eastern Africa.

Larson, G., Dobney, K., Albarella, U., Fang, M., Matisoo-Smith, E., Robins, E., et al. (2005). Worldwide phylogeography of wild boar reveals multiple centers of pig domestication. Science, 307(5715), 16181621.

Larson, G., Albarella, U., Dobney, K., Rowley-Conwy, K., Schibler, J., Tresset, A., et al. (2007). Ancient DNA, pig domestication, and the spread of the Neolithic into Europe. Proceedings of the National Academy of Science, 104, 15276-15281.

Larson, G., Liu, R., Zhao, X., Yuan, J., Fuller, D. Q., Barton, L., et al. (2010). Patterns of East Asian pig domestication, migration, and turnover revealed by modern and ancient DNA. Proceedings of the National Academy of Science, 107(17), 7686-7691.

Larson, G., Karlsson, E. K., Perri, A., Webster, M. T., Ho, S. Y. W., Peters, J., et al. (2012). Rethinking dog domestication by integrating genetics, archeology, and biogeography. Proceedings of the National Academy of Science, 109(23), 8878-8883.

Lightfoot, K. G. (2005). Indians, missionaries, and merchants: The legacy of colonial encounters on the California frontiers. Berkeley: University of California Press.

Ludwig, A., Pruvost, M., Reissmann, M., Benecke, N., Brockmann, G. A., Castaños, P., et al. (2009). Coat color variation at the beginning of horse domestication. Science, 324, 485.

Lukmanji, Z. (1992). Women's workload and its impact on their health and nutritional status. Progress in Food and Nutritional Science, 16(2), 163-179.

MacDonald, K. C. (1992). The domestic chicken (Gallus gallus) in sub-Saharan Africa: A background to its introduction and its osteological differentiations from indigenous fowls (Numidinae and Fancolinus sp.). Journal of Archaeological Science, 19, 303-318.

MacDonald, K. C. (1995). Why chickens? The centrality of the domestic fowl in West African ritual and magic. In K. Ryan \& P. J. Crabtree (Eds.), The symbolic role of animals in archaeology (vol. 12, pp. 50-56, MASCA Research Papers in Science and Archaeology). Philadelphia: University of Pennsylvania Museum of Archaeology and Anthropology.

Marshall, F. B. (2000). The origins and spread of domestic animals in East Africa. In K. MacDonald \& R. Blench (Eds.), African livestock: The new synthesis, archaeology, linguistics, DNA (pp. 191-221). Washington, D.C.: UCL Press.

Marshall, F. B., \& Weissbrod, L. (2010). The consequences of women's use of donkeys for pastoral flexibility: Maasai ethnoarchaeology. Documenta Archaeolobiologiae, 7, 55-75.

Mauss, M. (1923 [2000]). The gift: The form and reason for exchange in archaic societies New York: W. W. Norton.

McCabe, T. T. (1990). Success and failure: The breakdown of traditional drought coping institutions among the pastoral Turkana of Kenya. Journal of Asian and African Studies, 25(3/4), 146-160.

McIntosh, S. K., \& Scheinfeldt, L. B. (2012). It's getting better all the time: Comparative perspectives from Oceania and West Africa on genetic analysis and archaeology. African Archaeological Review, 29(2/3), $131-170$.

Muigai, A. W. T., \& Hanotte, O. (2013). The origin of African sheep: Archaeological and genetic perspectives. African Archaeological Review, 30(1).

Mwacharo, J. M., Bjørnstad, G., Jianlin, H., \& Hanotte, O. (2013). The history of African village chickens: An archaeological and molecular perspective. African Archaeological Review, 30(1). 
O’Brien, S. J., Johnson, W., Driscoll, C., Pontius, J., Pecon-Slattery, J., \& Menotti-Raymond, M. (2008). State of cat genomics. Trends in Genetics, 24, 268-279.

Ocaido, M., Muwazi, R. T., \& Asibo Opuda, J. (2009). Disease incidence in ranch and pastoral livestock herds around Lake Mburo National Park, in South Western Uganda. Tropical Animal Health and Production, 41, 1299-1308.

Pérez-Pardal, L., Royo, L. J., Beja-Pereira, A., Curik, I., Traoré, A., Fernández, I., et al. (2010). Y-specific microsatellites reveal an African subfamily in taurine (Bos taurus) cattle. Animal Genetics, 41(3), 232241.

Peters, J., Dieckmann, U., \& Vogelsang, R. (2010). Losing the spoor: Hail|om animal exploitation in the Etosha region. Documenta Archaeolobiologiae, 7, 99-181.

Popelka, R. S., Glascock, M. D., Robertshaw, P. T., \& Wood, M. (2005). Laser ablation-ICP-MS of African glass trade beads. In R. J. Speakman \& H. Neff (Eds.), Laser ablation ICP-MS in archaeological research (pp. 85-93). Albuquerque: University of New Mexico Press.

Ray, K. J., \& Ray, C. G. (Eds.). (2004). Sherris medical microbiology (4th ed.): McGraw Hill.

Reynolds, L. P. (2009). Perspectives: The decline of domestic animal research in agriculture and biomedicine. Journal of Animal Science, 87, 4181-4182.

Rubin, C.-J., Zody, M. C., Eriksson, J., Meadows, J. R. S., Sherwood, E., Webster, M. T., et al. (2010). Whole genome sequencing reveal loci under selection during chicken domestication. Nature, 464, 587-591.

Russell, N. (2012). Social zooarchaeology. Cambridge: Cambridge University Press.

Smith, A. B. (2005). African herders: Emergence of pastoral traditions. Walnut Creek: AltaMira Press.

Smith, A. B. (2011). Problems in the concept of 'Neolithic' expansion in Southern Africa. Paper presented at the Eurobabel Workshop: Methodology in linguistic prehistory, Humboldt University, Berlin, 15-16 October 2011.

Stahl, A. B. (1999). Perceiving variability in time and space: The evolutionary mapping of African societies. In S. K. McIntosh (Ed.), Beyond chiefdoms: Pathways to complexity in Africa (pp. 39-55). Cambridge: Cambridge University Press.

Stahl, A. B. (2002). Colonial entanglements and the practices of taste: An alternative to logocentric approaches. American Anthropologist, 104, 827-845.

Stahl, A. B. (2004). Political economic mosaics: Archaeology of the last two millennia in tropical SubSaharan Africa. Annual Review of Anthropology, 33, 145-172.

Stock, F., \& Gifford-Gonzalez, D. (2013). Genetics and African cattle domestication. African Archaeological Review, 30(1).

Tishkoff, S. A., Reed, F. A., Ranciaro, A., Voight, B. F., Babbitt, C. C., Silverman, J. S., et al. (2007). Convergent adaptation of human lactase persistence in Africa and Europe. Nature Genetics, 39, 31-40.

Wood, M. (2011). A glass bead sequence for southern Africa from the 8 th to the 16th century AD. Journal of African Archaeology, 9(1), 67-84.

Zeder, M. A. (2012). Biodiversity in agriculture: Domestication, evolution, and sustainability. In P. Gepts, T. R. Famula, R. L. Bettinger, S. B. Brush, A. B. Damania, P. E. McGuire, et al. (Eds.), Pathways to animal domestication (pp. 227-259). Cambridge: Cambridge University Press. 